\title{
Defining a quality index for electric power utilities using multiple criteria decision support and time series analysis
}

\author{
Definição de um índice de qualidade para distribuidoras de \\ energia elétrica utilizando o apoio à decisão multicritério \\ e análise de séries temporais
}

\author{
Aderson Campos Passos ${ }^{1}$ \\ Reinaldo Castro Souza ${ }^{1}$
}

\begin{abstract}
This paper presents a hybrid multi-criteria method developed through the combination of the Analytical Hierarchy Process (AHP) and exponential smoothing techniques applied in time series forecasting. To illustrate its use, a model was developed with the aim of creating a quality index for electric power distribution utilities. The conclusions highlight the need to take into account the results obtained in the latest months for those utilities, but giving less attention to those obtained in the earlier months. This characteristic of the problem led to the idea of incorporating the mathematical formulation of the exponential smoothing into the aggregation function of the AHP. At the end, the utility company is given a score between 0 (zero) and 10 (ten).
\end{abstract}

Keywords: Hybrid multi-criteria method. AHP. Exponential smoothing. Quality index. Electric power distribution utilities. Reduction of interdependence between criteria.

Resumo: Este trabalho apresenta um método multicritério híbrido construído através da fusão entre o Método de Análise Hierárquica (AHP) e técnicas de Amortecimento Exponencial, aplicadas na previsão de séries temporais. Para ilustrar a sua utilização foi construído um modelo com a finalidade de criar um índice de qualidade para distribuidoras de energia elétrica. As conclusões apresentadas revelam a necessidade de levar em consideração os resultados obtidos em meses anteriores por essas distribuidoras, mas dando menor importância a períodos mais distantes do tempo presente. Essa característica do problema sugeriu a idéia de incorporar a formulação matemática do amortecimento exponencial à função de agregação do AHP. Ao final é fornecida para a distribuidora avaliada uma nota entre 0 (zero) e 10 (dez).

Palavras-chave: Método multicritério híbrido. AHP. Amortecimento exponencial. Índice de qualidade. Distribuidoras de energia elétrica. Redução da interdependência entre critérios.

\section{Introduction}

There is a constant concern of the regulatory authority of the Brazilian electric sector (Electric Energy National Agency, ANEEL) to maintain performance measures that serve as references for the improvement of services provided by electricity distributing utilities. There are several existing indexes used. And as an example one can mention: the service level in call centers, DEC values, FEC values and IASC index. These performance measures have two basic purposes. The first is to give to ANEEL mechanisms to understand how the distributors are providing their services. The other is to serve as a reference for the companies to realize what they need to do to get good results. However, it is not used a global index for the national regulator to serve as a

general reference aggregating all relevant aspects to be followed by a distributor.

This article proposes that quality index for electric power distribution utilities. It is built using a hybrid method that uses multi-criteria decision support elements and time series analysis. This was done to make it possible to have a simultaneous view of several aspects that must be taken into account in the definition of quality indices monthly, and thereafter adding these values taking into account the results obtained in the past. The final result is a unique number which reflects the service quality that the utility has provided the last few months, offering a score between 0 (zero) and 10 (ten). This work is a continuation of a similar developed by Villela (2009). In it, the proposed

\footnotetext{
Departamento de Engenharia Elétrica, Pontifícia Universidade Católica do Rio de Janeiro - PUC-Rio, Rua Marquês de São Vicente, 225, Gávea, CEP 22451-900, Rio de Janeiro, RJ, Brasil, e-mail: aderson@ puc-rio.br; reinaldo@ele.puc-rio.br
} 
index is constructed differently using the MACBETH multi-criteria method (SANCHEZ-LOPEZ; BANA E COSTA, 2009).

The multi-criteria method used in the construction of the hybrid method is the Analytic Hierarchy Process (AHP) and to permit aggregation of past data it is used the concept of exponential smoothing. The merge of the two techniques was made similarly to a group decision making where deciders have different weights. However, instead of several decision makers there is the behavior of the distributor in previous months. This "behavior" is represented by an index indicating monthly performance of the evaluated utility company. The final result shall take into account the current and all previous results. However, their weights reduce with the increase of its distance from the present time.

Similar work was written by Rafaeli and Müller (2007). Therein it was proposed a consolidated index of performance for companies, using the AHP as a tool to aggregate several existing indicators, and obtaining another overall performance value. It is possible to find in the scientific literature several studies using the AHP to measure the performance of organizations (SUWIGNJO; BITITCI; CARRIE, 2000; BITITCI; SUWIGNJO; CARRIE, 2001; SARKIS, 2003; KIM; KIM, 2009). Other works dealing with the use of multi-criteria analysis for performance evaluation were made by Sellitto, Borchardt and Pereira (2006) and Rafaeli (2009). The fundamental difference is that the hybrid method consolidates past results (obtained from previous periods) in the present time.

It is noteworthy that this work has been entirely developed in academia, imagining how the representatives of ANEEL would think. Thus, the structure of the model and all judgments entered were made by experts from Pontifical Catholic University of Rio de Janeiro. In case of further adoption of this model by the regulator it is natural that modeling is modified or adapted to their preferences.

\section{Literature review: AHP and exponential smoothing}

The proposed hybrid method has its basis in AHP and adds elements of time series analysis using the exponential smoothing. In order to understand this model it will be shown the general concepts of AHP to further clarify how the exponential smoothing contributes to the hybrid method. AHP is a multi-criteria method developed by Thomas L. Saaty in the 1970s. Many articles and books have been written to talk about this method (SAATY, 1990, 1987a, b, 2006, DYER; FORMAN, 1992; MILLET; HARKER, 1990; HARKER, 1987) and this popularity is so evident that during the 1980s it was already possible to find survey articles about this subject (ZAHEDI, 1986).

One of the main features, and what gives the name of the method, is the possibility of organizing the decision criteria in a hierarchical structure, as an inverted tree. Thus, the structuring of the decision problem is evident and its approach made easier. Figure 1 illustrates the general hierarchical structure to the method.

The approach using this method takes a few steps. They are: 1) structuring the decision problem and definition of criteria, 2) determining the relative importance between criteria, 3) determining the relevant alternatives to the problem, 4) determining the judgments about the alternatives against the criteria, 5) aggregating the judgments and obtaining the final result, 6) sensitivity analysis. For the proposed hybrid method the steps are the same.

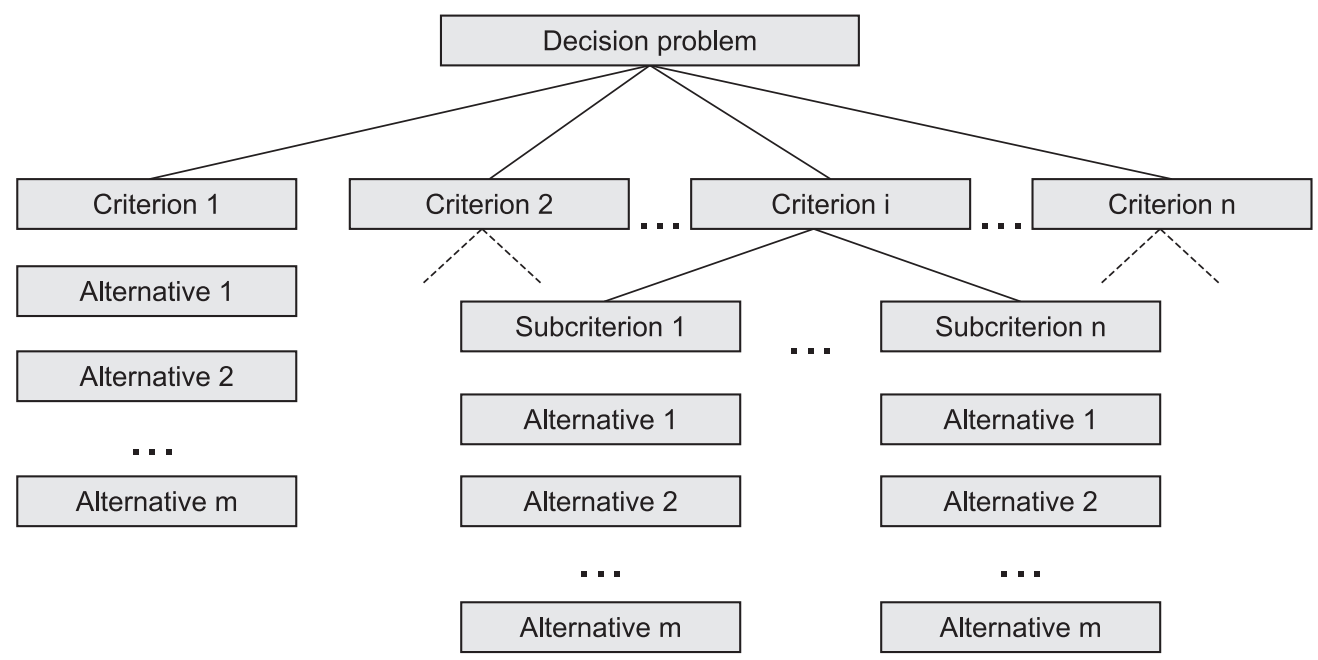

Figure 1. Hierarchical structure, adapted from Ribeiro, Passos and Teixeira (2012). 
To structure the problems the decision maker must raise the appropriate criteria for the problem and group them by following the guidelines of Keeney and Raiffa (1993) so that the hierarchical structure is constructed properly and has the following characteristics: completeness, minimum size, non-redundancy, operationality and decomposability. This way, the relative importance of the criteria is established by judgments made on the Saaty's fundamental scale shown in Table 1.

These judgments must be entered into a pairwise comparison matrix (Table 2) which is a square matrix that contains in its core, the values extracted from the fundamental scale or its inverse. As it is a ratio scale, each number indicates how many times one criterion is more important than the other. For example, if the criterion $\mathrm{p}$ is strongly more important than the first criterion, the value $\mathrm{a}_{\mathrm{p} 1}$ is replaced by the number 5 . This indicates that the criterion $\mathrm{p}$ is 5 (five) times more important than criterion 1 . The symmetrical values of the main diagonal are the inverse of one another. Thus, if $\mathrm{a}_{\mathrm{p} 1}=5$ the symmetric is $\mathrm{a}_{1 \mathrm{p}}=1 / 5$. It is also part of the method the analysis of inconsistencies of the judgments, made in each of these matrices. This measure of inconsistency should not exceed certain limits. The details of this approach will not be treated here.

The determination of relevant alternatives is also very important. In order to avoid decisions made on inappropriate alternatives, extensive research is needed. In the next step these alternatives are evaluated under the vision of these criteria. Two procedures can be adopted: the relative measurement and absolute measurement. In the relative measurement, the alternatives are compared in the view of each criterion, using the pairwise comparison matrix similarly to that carried out to evaluate the importance of

Table 1. Saaty's fundamental scale (SAATY, 2006).

\begin{tabular}{cl}
\hline Numerical scale & \multicolumn{1}{c}{ Verbal scale } \\
\hline 1 & Equal importance \\
3 & Moderate importance \\
5 & Strong importance \\
7 & Very strong importance \\
9 & Extreme importance \\
$2,4,6,8$ & Intermediate values \\
\hline
\end{tabular}

Table 2. Example of pairwise comparison matrix.

\begin{tabular}{cccccc}
\hline Criterion & Crit1 & $\ldots$ & Crit p & $\ldots$ & Crit n \\
\hline Crit1 & 1 & $\ldots$ & $\mathrm{a}_{1 \mathrm{p}}$ & $\ldots$ & $\mathrm{a}_{1 \mathrm{~m}}$ \\
$\ldots$ & $\ldots$ & $\ldots$ & $\ldots$ & $\ldots$ & $\ldots$ \\
Crit p & $\mathrm{a}_{\mathrm{p} 1}$ & $\ldots$ & 1 & $\ldots$ & $\mathrm{a}_{\mathrm{pm}}$ \\
$\ldots$ & $\ldots$ & $\ldots$ & $\ldots$ & $\ldots$ & $\ldots$ \\
Crit $\mathbf{n}$ & $\mathrm{a}_{\mathrm{m} 1}$ & $\ldots$ & $\mathrm{a}_{\mathrm{mp}}$ & $\ldots$ & 1 \\
\hline
\end{tabular}

the criteria. However, this is not the focus of this work. In absolute measurement, often used when the number of alternatives to be evaluated is very large, are established categories of assessments or value functions, which will serve as a reference for scoring these alternatives in light of the criteria. It is important that the values generated by these functions remain normalized or in the same scale range of the values for each criterion.

The traditional aggregation procedure of AHP is linear and additive, i.e. each alternative is scored as a linear combination of the weights of the alternative values against criteria, as shown below,

$$
f(a)=\sum_{j=1}^{n} w_{j} v_{j}(a)
$$

where:

- $w_{j}=$ weight of the $\mathrm{j}$-th criterion;

- $v_{j}=$ value of the alternative " $a$ " against the $\mathrm{j}$-th criterion.

Sensitivity analysis is an important step in the completion of this kind of model. The established values for the different parameters can be analyzed again, in order to evaluate the impact on the model. It is common that in decision analysis there are doubts about the judgments on the weights of criteria and values assigned to the alternatives against criteria, especially if those judgments are qualitative. The sensitivity analysis enables dubious values to be reviewed. Furthermore it is possible to analyze its impact on the final result.

A time series is a set of ordered pairs (x,y) where an element of such pair is always associated to time. Studying the behavior of time series can be very useful for several purposes. Among them the most common and popular is to produce forecasts. There are several statistical procedures for forecasting time series. One of the oldest is the method of moving averages.

In the Simple Moving Average Method (SMAM) the estimator $\hat{\mu}_{t}(N)$ is calculated as the mean average of the elements from the historical series $\mathrm{Z}_{\varphi}$. Thus,

$$
\begin{aligned}
& \hat{\mu}_{t}(N)=M_{N}=\frac{Z_{1}+\ldots+Z_{N}}{N}, \text { or generically } \\
& \hat{\mu}_{t}(N)=M_{T}=\frac{Z_{T-N+1}+\ldots+Z_{T-1}+Z_{T}}{N}
\end{aligned}
$$

It is important to observe that the forecast $\mathrm{h}$ steps ahead is the same. For this reason,

$$
\hat{Z}_{t}(h)=M_{T}=\frac{Z_{T-N+1}+\ldots+Z_{T-1}+Z_{T}}{N}
$$

This value is updated whenever new values are inserted into the series. In this case the older value leaves the series and is replaced by the newer. For this reason, the method name is called moving averages. It is possible to define a recursive form for the moving average $\mathrm{M}_{\mathrm{T}}$. In this form we have: 


$$
M_{T}=M_{T-1}+\frac{Z_{T}-Z_{T-N}}{N}
$$

The moving average approach has a serious drawback. It is related to the parameter estimation, where all past values receive the same weight $(1 / \mathrm{N})$. This is not adequate, in the sense that recent observations should receive more weight than past ones. This idea will be used ahead on the estimation of the quality index.

From the recursive Equation 1 it is possible to derive the following expression:

$$
M_{T}=M_{T-1}+\frac{Z_{T}}{N}-\frac{Z_{T-N}}{N}
$$

Taking $\mathrm{M}_{\mathrm{T}-1}$ as an estimator of $\mathrm{Z}_{\mathrm{T}-\mathrm{N}}$ one can write:

$$
M_{T}=\frac{1}{N} Z_{N}+\left(1-\frac{1}{N}\right) M_{T-1}
$$

Substituting $\frac{1}{N}$ above by $\alpha$ we arrive at:

$$
\hat{\mu}_{t}(N)=M_{T}=\alpha Z_{N}+(1-\alpha) M_{T-1}
$$

Equation 2 represents a procedure known as exponential smoothing. The value $\alpha$ is known as exponential constant and is a real number between 0 and 1. By successive substitution in Equation 2, the following expression for $\mathrm{M}_{\mathrm{T}}$ is obtained:

$$
\begin{gathered}
\hat{\mu}_{t}(N)=M_{T}=\alpha Z_{N}+\alpha(1-\alpha) Z_{N-1}+ \\
\alpha(1-\alpha)^{2} Z_{N-2}+\ldots+\alpha(1-\alpha)^{T} M_{o}
\end{gathered}
$$

A closer look at the above equation shows that the historical values are weighted in a different way; the older ones receive smaller weights. The starting value $\mathrm{M}_{\mathrm{o}}$ is usually taken as the average of the first four observations, or even like the first observation. $\mathrm{M}_{\mathrm{o}}=\mathrm{Z}_{1}$ (MORETTIN; TOLOI, 2006).

\section{Theoretical backgroud: the hybrid method}

The hybrid method proposed here uses a different way of aggregation. It takes into account the past judgments, but receiving decreasing weight according to their distance to the present period. Equation 3 displays the final values of each alternative, obtained by the hybrid method:

$$
v_{d}=\sum_{t=0}^{N} \alpha(1-\alpha)^{t} v(t)
$$

where:

- $v_{d}=$ final value of the alternative;

- $\alpha=$ constant defined between 0 (zero) and 1 (one); and

- $N=$ number of periods considered in the problem.
The values of the alternative $v(t)$ at period $t$ is given by Equation 4 shown below:

$$
v(t)=\sum_{j=1}^{n} w_{j} v_{j}(t)
$$

where:

- $w_{j}=$ weight associated to criterion $\mathbf{j}$;

- $v_{j}(\mathrm{t})=$ value of the alternative $\mathrm{j}$, at time $\mathrm{t}$.

Equation 4 is very similar to the traditional aggregation procedure of the AHP. The only difference is that in the former there is no time variation. Equation 3 comes from the time series forecasting equation used in the exponential smoothing method (MORETTIN; TOLOI, 2006). In this equation, the factors closer to the present period receive a higher weight and, as a consequence, a higher contribution to the final values for the index $\mathrm{v}_{\mathrm{d}}$.

\section{Quality index for an electric power utility}

The aim to construct a quality index for an electrical energy utility is, primarily, to evaluate the quality of the services it provides to its customers. For such a complex sector this becomes a rather important task, as it is the tool that the utility should use to improve on the quality of its services, and, as an immediate consequence, to increase the value of the index. Therefore, in order to define the format to evaluate the utilities, one should take into account, simultaneously, various factors. In what follows, the approach presented in section 2 will be thoroughly used to provide a solution to this problem.

\section{Step 1: Structuring the problem and defining the criteria}

From the set of initial criteria (Figure 2), some of them were selected to create the final hierarchical structure that formed the basis to create the index.

This set was reduced in order to meet the recommendations of Keeney and Raiffa (1993) already described in section 2 . The first one of these deals with the completeness, i.e. the set of criteria should include everything that is important in the decision process. In contrast to this recommendations, come other two; minimum size and absence of redundancy. The first one states that the set of criteria should not be excessively large; it should contain the minimum number of criteria for the solution being proposed. The latter, states that the criteria that form the hierarchical structure of the problem should not at all be redundant. The fourth recommendation is known as the operationality. It states that, the criteria that will be really used in the evaluation (those in the lower part of the hierarchical structure) should carry the necessary specification in order to allow their evaluation. Further ahead it will be possible to observe that this shall happen, as the five criteria chosen to set the model have the necessary 


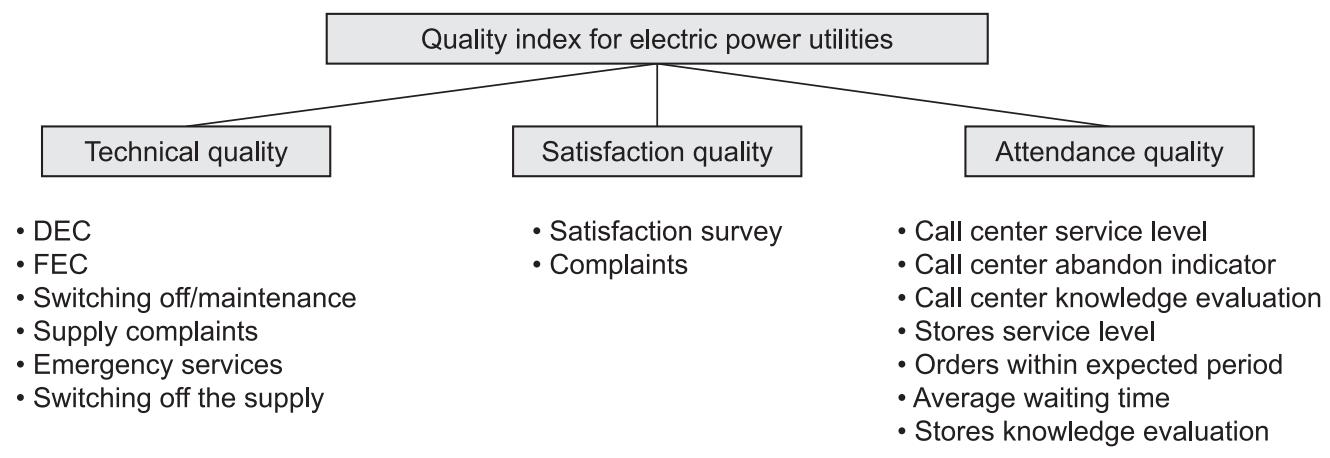

Figure 2. Initial hierarchical structure obtained from the interviews.

specification to be evaluated. The fifth recommendation is the decomponibility. Decomponible criteria are those where the performance of an alternative with respect to a criterion is not affected by the performance of any other criterion. To help removing the redundant criteria it was used the method known as the Method of Heuristic Minimization of Criteria Interdependence (MMHI for short). In this method the criteria selected initially via the interviews are pairwise compared. In this comparison, the decision maker is directed to the analysis of possible dependencies among these criteria (GOMES; DAMÁZIO; ARAÚJO, 1992). Before the analysis with the MMHI, it will be described the criteria that form the hierarchical structure of Figure 2.

DEC: it is an index that reflects the average period per consumer that the utility clients have had power cut in their premises (KAGAN; OLIVEIRA; ROBBA, 2005). The electrical utilities estimate this index frequently and this makes it possible to use it in the model. There exists a target value for the DEC of each utility, set by ANEEL. To meet this target is a permanent task for the utility, otherwise, they may be penalized by ANEEL. The estimation of the DEC is carried out as shown below:

$$
D E C=\frac{\sum_{i=1}^{N} C a(i) \times t(i)}{C_{S}}
$$

where:

- $\mathrm{Ca}(\mathrm{i})=$ is the number of consumers of the universe affected by power cut $i$;

- $\mathrm{t}(\mathrm{i})=$ is the time duration (usually measured in minutes) of the power failure $\mathrm{i}$; and

- $\mathrm{C}_{\mathrm{S}}=$ is the total number of consumers affected by power failure $i$.

FEC: it is an index that reflects the frequency, i.e., the average number of times per consumer that there have been power cut. In a similar way to the DEC index, there are target values for the FEC, also set by ANEEL. The estimation of this index is shown next.

$$
F E C=\frac{\sum_{i=1}^{N} C a(i)}{C_{S}}
$$

where:

- $\mathrm{Ca}(\mathrm{i})=$ is the number of consumers of the universe affected by power cut $\mathrm{i}$;

- $\mathrm{C}_{\mathrm{S}}=$ is the total number of consumers affected by power failure $i$.

Switching off/Maintenance (Mnt): are the previously programmed power cut for maintenance purposes only.

Supply complaints: there are three categories of complaints considered in this criterion: complaints of constant power failure, complaints related to the connection and emergency complaints.

Emergency services: it reflects the number of emergency calls that happen within a certain period. It is included into this category the calls originated by events that threat the personal security or those that may interfere on the quality of the service provided.

Switching off the supply: are the non-programmed power cut, out of the utility control.

Satisfaction survey: there are two satisfaction surveys that were initially considered to express the meaning of this criterion; the IASC survey and the ABRADEE (Brazilian association of the distributing utilities). ANEEL conducts once a year the survey among a sample of residential consumers within the concession area of each Brazilian distributing utility and produces, as a result, the IASC index for each one of them. The observations used to estimate this index are obtained by direct door to door interviews with the consumers of the respective sample. The 
ABRADEE survey has a somehow similar objective, i.e., to generate a satisfaction index. However, it is fully sponsored and organized by ABRADEE itself.

Complaints: complaints of any nature received by the utility.

Service level: it represents the number of calls that were, in fact, answered within a generic universe. Mathematically, it is expressed by the following Equation 5:

$$
N S=\frac{\text { Total } C R}{\text { TotalCR }+ \text { Total } C N R} \times 100
$$

where:

- $\mathrm{NS}=$ generic equation of the service level;

- $\mathrm{CR}=$ calls received in a certain period; and

- $\mathrm{CNR}=$ non received call in a certain period.

The concept of service level will be the same for both; number of answers at the "call center" and the number of calls at the utility offices.

Abandon indicator: is the ratio between the number of abandon calls and the total number of calls received by the attendees in the call centers.

Table 3. Analysis of the sub-criteria of the criterion Satisfaction Quality.

\begin{tabular}{|c|c|c|}
\hline & 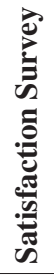 & 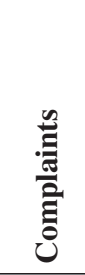 \\
\hline Satisfaction Survey & & VINT \\
\hline Complaints & & \\
\hline
\end{tabular}

Knowledge evaluation: it is the result of an evaluation test that the utility attendees of the offices and the call centers have to submit themselves every three months to check whether these employees are aware of the answering protocols to deal with the consumers queries and also, to test their ability to answer correctly the consumer queries.

Order within expected period: Is the total number of maintenance service orders that are carried out within the expected period established by the utility.

Average waiting time: is the ratio between the total waiting time of all consumers on the queue awaiting to be served and the total number of these clients.

Once the person in charge of the evaluation concludes its analysis, he (or she) will decide upon this interdependency. Three proposals are formulated: a) very interdependent (VINT), b) interdependent (INT) and c) independent (IND). The analysis was started by grouping the sub-criteria of the three main criteria as illustrated in Tables 3, 4 and 5. When very interdependent criteria are found, one should choose which ones are to be excluded. If an interdependent evaluation is found, one should examine the need of its exclusion. Finally, when the criteria are independent, there is no need of exclusions.

The analysis shown in Table 3 considers the criteria: Satisfaction survey and Complaints. The interdependency between these two is quite clear, as these satisfaction surveys are strongly related to the amount of complaints received by the utility. Therefore, one of these two criteria has to be excluded. In the present case, the complaint criterion was excluded, due to the fact that it is easier to obtain information on the satisfaction survey.

In the analysis shown in Table 4, the interdependency between the criterion DEC and the

Table 4. Analysis of the criterion Technical Quality.

\begin{tabular}{|c|c|c|c|c|c|c|}
\hline & 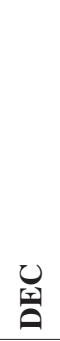 & $\underset{I}{U}$ & 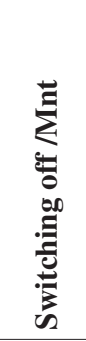 & 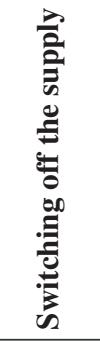 & 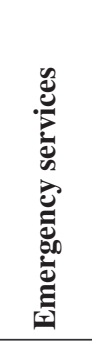 & 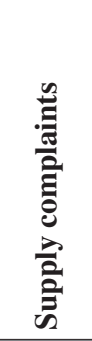 \\
\hline DEC & & IND & IND & VINT & VINT & VINT \\
\hline FEC & & & IND & VINT & VINT & VINT \\
\hline Switching off /Mnt & & & & IND & IND & IND \\
\hline Switching off the supply & & & & & VINT & VINT \\
\hline Emergency services & & & & & & VINT \\
\hline Supply complaints & & & & & & \\
\hline
\end{tabular}


criteria Emergency services, Switching off the supply and Supply complaints is quite clear, as these criteria are, somehow, related to the supply of energy. In a similar way, there is a strong dependency among these last three criteria and the FEC criterion. A similar rationing was used to analyze the others cells of the table. Therefore, the criteria switching off the supply, emergency services and supply complaints were excluded. The criterion switching off/ maintenance was also excluded from the model. However, this decision was due to the fact that the corresponding information was hard to be obtained.

From Table 5 below, one can see that there are many interdependencies among the sub-criteria associated to the Service Quality. Indeed, from the definition of the service level and abandon indicator it is possible to check this interdependency. The service level is also interdependent with knowledge evaluation, as the bad or good staff training has a direct impact on the quality of the attendance. The service level is also interdependent with the knowledge evaluation as the bad or good staff training has a direct impact on the quality of the attendance. For another reasons, one can conclude that there is interdependency among the criteria: service level (at the utility stores), orders within the expected period, average waiting time (within the utility stores) and the service level (at the utility call center). It is quite natural to expect

Table 5. Analysis of the criterion Attendance Quality.

\begin{tabular}{|c|c|c|c|c|c|c|c|}
\hline & 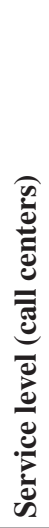 & 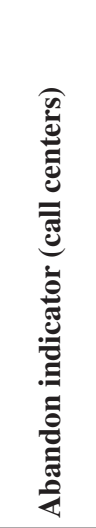 & 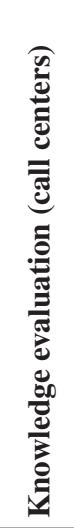 & 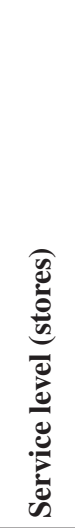 & 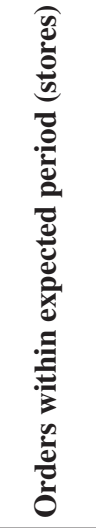 & 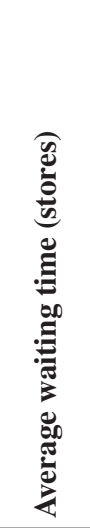 & 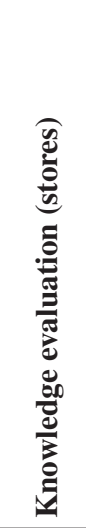 \\
\hline Service level (call centers) & & VINT & INT & INT & INT & INT & IND \\
\hline Abandon indicator (call centers) & & & IND & INT & IND & IND & IND \\
\hline Knowledge evaluation (call centers) & & & & INT & IND & IND & IND \\
\hline Service level (stores) & & & & & VINT & VINT & INT \\
\hline Orders within expected period (stores) & & & & & & VINT & VINT \\
\hline Average waiting time (stores) & & & & & & & INT \\
\hline Knowledge evaluation (stores) & & & & & & & \\
\hline
\end{tabular}

Table 6. Criteria used to form the index.

\begin{tabular}{|c|c|c|c|c|c|}
\hline & 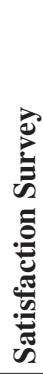 & 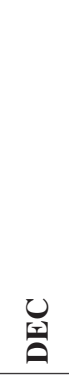 & U & 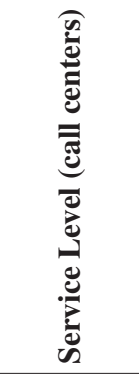 & 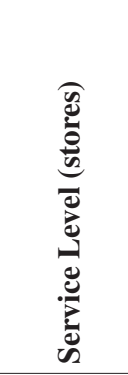 \\
\hline Satisfaction Survey & & INT & INT & IND/INT & INT/IND \\
\hline DEC & & & IND & INT & IND \\
\hline FEC & & & & INT & IND \\
\hline Service Level (call centers) & & & & & INT \\
\hline Service Level (stores) & & & & & \\
\hline
\end{tabular}


that service level (at the utility shops) is highly interdependent with orders within the expected period and the average waiting time to be served at the offices. After conducting a similar procedure in all cells of the table, it was concluded that the following criteria should be removed: service level (at the utility shops), abandon indicator (at the call center), average waiting time (within the utility stores), and orders within expected period (utility stores).

After removing the redundancies, table 6 displays the criteria used to construct the index.

The above analysis showed that the presence of interdependency among the criteria do exist, though somehow light, but they were adequate to be considered in the construction of the model. According to Gomes, Damásio and Teixeira (1992) the complete elimination of interdependency is rather rare. Once the choice of the criteria has been made and the hierarchical structure of the problem selected (Figure 3), the next step is the selection of the corresponding relative weights.

\section{Step 2: Determining the relative importance} among the criteria

The assignment of the weights was carried out using a pairwise comparison matrix as shown in Table 2. The elements of this matrix were filled using the judgments of the decision makers expressed by the fundamental scale of Saaty (Table 1). The AHP method includes an inconsistency analysis of this matrix which, in the present model, reached acceptable values, according to the method. Other

Table 7. Criteria weights.

\begin{tabular}{lc}
\hline \multicolumn{1}{c}{ Criteria } & $\begin{array}{c}\text { Relative } \\
\text { weight }\end{array}$ \\
\hline Satisfaction index & 0.35 \\
DEC & 0.225 \\
FEC & 0.225 \\
$\begin{array}{l}\text { Level of Services } \\
\text { (call center) }\end{array}$ & 0.1 \\
$\begin{array}{l}\text { Level of Services } \\
\text { (shops) }\end{array}$ & 0.1 \\
\hline
\end{tabular}

details of the inconsistency analysis will be omitted. The vector of weights is described in Table 7.

\section{Step 3: Determining relevant problem alternatives}

In this problem only one alternative is being analyzed, in the present case, an electricity power utility. By using its information it will be possible to obtain its final score.

\section{Step 4: Determining the judgments about alternatives against the criteria}

The next stage is the evaluation of the utility based on each one of the criteria. For each one of them it will be defined a value function that express the magnitude of the criterion as a score between 0 (zero) and 10 (ten). These functions built based on the defined criteria have the following characteristics:

Satisfaction Survey: To simplify the research and avoid ambiguities it was used the IASC satisfaction index in this criterion. The final value of this index is a score between zero and ten for the utility estimated from the results of the survey. It is important to mention that the highest score received by a utility ever in Brazil was 8.119 (SALA DE IMPRENSA, 2009). Therefore, the value function considered to evaluate the utility will be:

$$
\text { Satisfaction survey }=\frac{x}{81,19} \times 10
$$

where:

- $\mathrm{x}=$ is the satisfaction score (IASC) of the utility. Its values will be defined between 0 and 100 .

If, in any survey, a utility receive a greater score, it will be used in the denominator of the equation above.

DEC: to express the result of the utility in this criterion, it was defined Equation 4 as the value function to carry out this quantification:

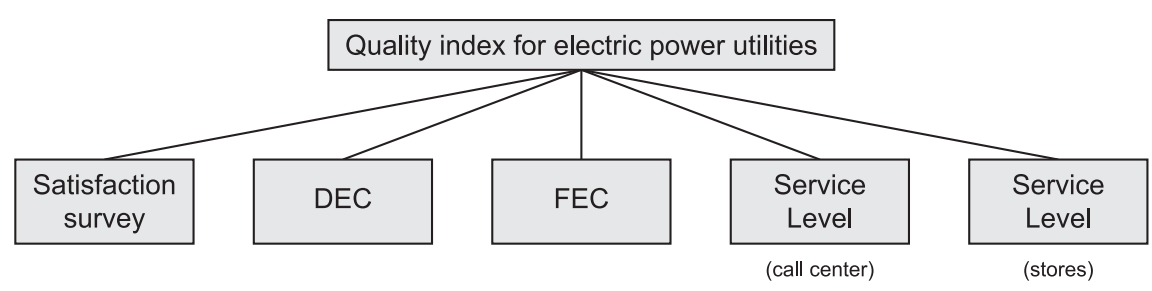

Figure 3. Final hierarchical structure for the quality index. 


$$
v_{D E C}(x)=\left\{\begin{array}{l}
10, \quad 0 \leq x \leq 1 / 2 y \\
\frac{12 y-4 x}{y}, \quad 1 / 2 y \leq x \leq 3 y \\
0, \quad \text { other values }
\end{array}\right.
$$

where:

- $v_{D E C}(x)=$ is the value function that is defined between 0 and 10;

- $x$ = represents the value of the DEC estimated for the utility; and

- $y=$ represents the DEC target value for that period.

-

FEC: The corresponding value function was defined as follows:

$$
v_{F E C}(x)=\left\{\begin{array}{l}
10, \quad 0 \leq x \leq 1 / 2 y \\
\frac{12 y-4 x}{y}, \quad 1 / 2 y \leq x \leq 3 y \\
0, \quad \text { other values }
\end{array}\right.
$$

where:

- $v_{F E C}(x)=$ value function defined between 0 and 10 ;

- $x=$ represents the value of the estimated utility FEC; and

- $y=$ represents the target value for the FEC.

Service level at the "call center" and at the utility stores: due to the similarity of the procedure in the calculation of the value function the two criteria are shown in the same topic. In order to arrive at a score between 0 and 10 for a particular utility within this criterion (service level) it is reasonable to assume a similar condition to that obtained for the criterion satisfaction survey. Obtaining a service level score close to 10 must be a difficult task indeed. Therefore, it will be adopted a maximum value as reference in such a way that the obtained final result lies always between 0 and 10 .

Service level

$$
(\text { stores or call centers })=\frac{N S}{\text { Máx }(\mathrm{NS})} \times 10
$$
where:

- $\mathrm{NS}=$ service level at the stores (or at the call center), from Equation 5;

- $\operatorname{Max}(\mathrm{NS})=$ maximum service level at the stores (or at the call center) in a given period. This particular value may change in case it increases.

\section{Step 5: Judgments aggregation and obtaining the final result}

To illustrate the application of the hybrid method the relevant information to set a score (Table 8) from the utility under study was collected.

After the application of the functions (Equations 6, 7, 8 and 9) on the available collected data of Table 8, the values (between 0 and 10) for each evaluation criterion was obtained. The results are shown in Table 9:

The result shown in Table 10 comes from the application of Equations 3 and 4, taking as input values those from Table 9. From Table 10, one can see that the central column represents the monthly

Table 8. Information from a Brazilian electric power utility.

\begin{tabular}{lccccccc}
\hline & & \multicolumn{7}{c}{$\mathbf{2 0 0 8}$} \\
\cline { 3 - 7 } \multicolumn{1}{c}{ Criterion } & Weigths & Jan. & Feb. & Mar. & Apr. & May & June \\
\hline Satisfaction Survey (IASC) & $\mathbf{0 . 3 5 0}$ & 57.58 & 57.58 & 57.58 & 57.58 & 57.58 & 57.58 \\
DEC & $\mathbf{0 . 2 2 5}$ & 1.88 & 1.41 & 1.36 & 1.27 & 0.81 & 0.73 \\
Target - DEC & & 1 & 1.2 & 1.25 & 1.1 & 1 & 1.2 \\
FEC & $\mathbf{0 . 2 2 5}$ & 1.29 & 1.07 & 1.05 & 0.8 & 0.55 & 0.69 \\
Target - FEC & & 1 & 1.2 & 1.25 & 1.1 & 1 & 1.2 \\
Service Level (“call center") & $\mathbf{0 . 1 0 0}$ & 74.79 & 74.2 & 74.09 & 73.79 & 73.74 & 73.77 \\
Service Level (stores) & $\mathbf{0 . 1 0 0}$ & 82.61 & 81.86 & 79.55 & 79.53 & 79.9 & 81.2 \\
\hline
\end{tabular}

Table 9. Electric power utility processed data.

\begin{tabular}{lccccccc}
\hline \multicolumn{1}{c}{ Criterion } & Weigths & Jan. & Feb. & Mar. & Apr. & May & June \\
\hline Satisfaction Survey (IASC) & $\mathbf{0 . 3 5 0}$ & 7.03 & 7.03 & 7.03 & 7.03 & 7.03 & 7.03 \\
DEC & $\mathbf{0 . 2 2 5}$ & 4.48 & 7.30 & 7.65 & 7.38 & 8.76 & 9.57 \\
FEC & $\mathbf{0 . 2 2 5}$ & 6.84 & 8.43 & 8.64 & 9.09 & 9.80 & 9.70 \\
Service Level (“call center”) & $\mathbf{0 . 1 0 0}$ & 9.23 & 9.16 & 9.15 & 9.11 & 9.10 & 9.11 \\
Service Level (Shops) & $\mathbf{0 . 1 0 0}$ & 10.00 & 9.91 & 9.63 & 9.63 & 9.67 & 9.83 \\
\hline
\end{tabular}


Table 10. Final result obtained from the hybrid model.

\begin{tabular}{ccc}
\hline Month & $\mathbf{v}(\mathbf{t})$ & $\alpha(1-\alpha)^{t} v(t)$ \\
\hline Jan. & 6.93 & 0.043 \\
Feb. & 7.91 & 0.121 \\
Mar. & 8.00 & 0.307 \\
Apr. & 8.04 & 0.772 \\
May & 8.51 & 2.043 \\
June & 8.69 & 5.214 \\
$\mathbf{V}_{\mathbf{d}}$ & & $\mathbf{8 . 5 0 1}$ \\
\hline
\end{tabular}

quality index obtained from the utility at the months between January and June. This means that, by the application of Equation 3 for a fixed value $t$ (i.e. for a given month) it is possible to evaluate the quality of the service of the utility in that particular period, under the criteria of the model. The values of the right column show the share of each month in the final score $v_{d}$ (highlighted at the lower part of the table) The judgments closer to the present period have a higher contribution on the estimation of the final index.

\section{Step 6: Sensitivity analysis}

The sensitivity analysis is an important step in the construction of a multi-criteria model as the present one, specially in the case the model is adopted by the regulator body. In it, one can introduce changes in those judgments that he/she find not appropriate during the setting of the model. After that, the final response is analyzed and a decision is taken on the values to be adopted as the definite ones. The final score obtained (8.501 in the present case) is totally dependent on the model parameters (weights, value functions of the alternatives, the value set to $\alpha$, and the data from the utility). Changing any of these parameters results in a direct impact on this final score. Concerning the value for $\alpha$ there is a special point to be made; as it is responsible for the contribution of the previous months on calculation of the final score. This way, values of close to 1 indicates that only a few previous months are important in the calculation of the final score. If the regulator body opts to adopt such model these values should be registered in a clear manner for the utilities.

\section{Criticism to the AHP and impacts of the proposed hybrid model}

The AHP method has been the target of many criticisms in the scientific literature. Goodwin and Wright (2004) group a set of criticisms, some of them are mentioned below.

Reversing the order due to the inclusion of another alternative: this problem was raised by Belton and Gear (1983) and was solved by changing the normalization procedure used to derive the vector of weights from the pairwise comparison matrix.

Possibility of a great number of comparisons: the redundant comparisons may be an advantage, however, they require a great number of comparisons. This restricts the application of the method raising errors in the judgments.

Imposing inconsistencies by the 1 to 9 scale: this scale may produce inconsistencies. Assuming a criterion A three times more important than criterion B and this one four times more important than criterion C. This implies that criterion $\mathrm{A}$ is twelve times more important than criterion $\mathrm{C}$, and this is not possible due to the scale imposed by the method.

Conversion of the verbal scale to a numerical scale: some authors argue whether the correspondence between the numerical and verbal scales express the real judgments of the decision makers.

The last criticism, not mentioned in the book of Goodwin and Wright (2004) is presented below:

Using the eigenvector method in determining the weights of the criteria: in Bana e Costa and Vansnick (2008) it is shown some examples in which the judgments exposed by the decision makers are heavily distorted, after the calculation of the eigenvectors of the pairwise comparison matrix. When this matrix is calculated, the dominant relationship among criteria or alternatives is explicit, depending on what is being compared. What happens is the fact that after the estimation of the weights of the criteria, they may produce distortions on the preferences relationship.

The proposed hybrid method would suffer on step 2 (determination of the relative importance among the criteria) if the eigenvector method was used to estimate the vector of weights. However, this does not happen, as in it substitution, it is used the approach proposed by Saaty (2006). He suggests that this vector of weights may be calculated by taking the mean values of the rows of the matrix of pairwise comparisons, normalizing these mean values by the sum of all of them.

The criticism that considers the possibility of reverting the order is not a task of the hybrid method, as it calculates the alternative values based on the criteria using the function values described in step 4. Besides that, with the method employed, it carries out a classification instead of an ordering of alternatives, as used in the classical AHP.

The possibility of a great number of comparisons will not happen in this case, as the alternatives are evaluated through a value function. In fact, if these values were obtained according to the classical AHP, this problem could happen.

This method, on the other hand, is vulnerable to other criticisms that may constitute a limitation of the AHP itself. 


\section{Conclusions and analysis of the results}

The first contribution of this work is the presentation of the Method of Heuristic Minimization of Criteria Interdependence. Although it is reasonably old (1992), it does not often is shown in the specialized literature and this article is a real opportunity to show it out. The confrontation among criteria that it proposes is rather simple and, at the same time, introduces great value for the creation of well-ordered hierarchical structures.

Analyzing the obtained results, there is no doubt that the most important and innovative one was the development of the hybrid model. Departing from a multi-criteria framework and the concepts of time series analysis, it was possible to aggregate time varying indices for an electricity utility and evaluate it, arriving, in the end, at a quality index for the utility.

Another important characteristic to be emphasized is the way the electric power utility is being classified. Usually, the classification from a multi-criteria method are carried out by considering the alternatives within the categories (e.g. bad, regular, good, very good, excellent). This is usually adopted in various multi-criteria methodologies as Electre TRI (BRITO; ALMEIDA; MOTA, 2010; DIAS et al., 2002), UTADIS (ZOPOUNIDIS; DOUMPOS, 2002) etc. In this paper, the classification was simply made through a score varying from 0 (zero) to 10 (ten). It is possible that one wish to define categories over these values in order to set penalties or bonus for the utilities. In this case, its implementation is rather easy, similar to the grades it is adopted at schools.

A model like this has its academic value, however, its practical value depends very much on its adoption by the regulator body (ANEEL). It's obvious that an adaptation of the model is necessary, in order to standardize the input parameters, as well as the definition of the appropriate rules for the value functions that produce the scores between 0 (zero) and 10 (ten) for the DEC, FEC, satisfaction survey and level of services. This way, the same model can be used to any distributing utility

There are two possible ways to improve the proposed model. They are mainly associated to the information that will be used in its design. A representative of ABRACE (SOUSA, 2010) made a point on the importance of taking into account in the model setting, the quality of the energy supplied by the utility. This is, indeed, an important variable, however, there is not a formal way to extract it, due to the fact that ANEEL has not a standard procedure to estimate this quantity as it is the case for the DEC and the FEC. Another aspect also related to that is the existence of the necessary information to build the quality index. It does not make any sense to use the model if quality data is not at all available. Besides that, the criteria used may be questioned and this is part of the multi-criteria decision approach itself. Therefore, one could expect that other specialists may propose a different model to this problem. Likewise, the weights of the criteria may be set in at different values. However, all these possible discussion will cease to exist once the regulator comes up with official definition of the criteria and model parameters, defining, in a unique manner, the rules to be followed by all utilities. As one can see, the role of ANEEL is unquestionable if this quality index is to be adopted nationwide.

As a final word, it is also possible to conjecture the use of this hybrid method proposed here in the context of a financial market risk classification as carried out by the agencies such as: Standard \& Poor's and Moody's. In fact, analyzing this classification problem from a multi-criteria angle and having available historical data on previous classifications carried out by these agencies, it will be possible to take them into the model presented in this paper in a very elegant way.

\section{References}

BANA E COSTA, C. A.; VANSNICK, J. C. A critical analysis of the eigenvalue method used to derive priorities in AHP. European Journal of Operational Research, v. 187, p. 1422-1428, 2008. http://dx.doi. org/10.1016/j.ejor.2006.09.022

BELTON, V.; GEAR, T. On a short-coming of Saaty's Method of Analytic Hierarchies. Omega, v. 11, n. 3 , p. 277-230, 1983. http://dx.doi. org/10.1016/0305-0483(83)90047-6

BITITCI, U.; SUWIGNJO, P.; CARRIE, A. Strategy management through quantitative modeling of performance measurement systems. International Journal of Production Economics, v. 69, n. 1, p. 15-22, 2001. http://dx.doi.org/10.1016/ S0925-5273(99)00113-9

BRITO, A. J.; ALMEIDA, A. T.; MOTA, C. M. M. A multicriteria model for risk sorting of natural gas pipelines based on ELECTRE TRI integrating utility theory. European Journal of Operational Research, v. 200, p. 812-821, 2010. http://dx.doi.org/10.1016/j. ejor.2009.01.016

DIAS, L. et al. An aggregation/disaggregation approach to obtain robust conclusions with ELECTRE TRI. European Journal of Operational Research, v. 138, p. 332-348, 2002. http://dx.doi.org/10.1016/ S0377-2217(01)00250-8

DYER, R. F.; FORMAN, E. H. Group decision support with the Analytic Hierarchy Process. Decision Support Systems, v. 8, n. 2, p. 99-124, 1992. http://dx.doi. org/10.1016/0167-9236(92)90003-8

GOODWIN, P.; WRIGHT, G. Decision Analysis for Management Judgment. Chichester: John Wileyand Sons, 2004. 468 p. 
GOMES, L. F. A. M.; DAMÁZIO, H. N.; ARAÚJO, G. M. Minimização Heurística da Interdependência entre Critérios no Auxílio Multicritério à Decisão: uma Aplicação à Decisão sobre Seguro Ambiental para Transporte Rodoviário de Produtos Perigosos. Rio de Janeiro: Departamento de Engenharia Industrial, Pontifícia Universidade Católica do Rio de Janeiro, 1992. Relatório Técnico.

HARKER, P. T. Alternative modes of questioning in the analytic hierarchy process. Mathematical Modelling, v. 9, n. 3-5, p. 353-360, 1987. http://dx.doi. org/10.1016/0270-0255(87)90492-1

KAGAN, N.; OLIVEIRA, C. C. B.; ROBBA, E. J. Introdução aos Sistemas de Distribuição de Energia Elétrica. São Paulo: Editora Edgard Blücher, 2005. 328 p. Bibliografia: p. 279-287.

KEENEY, R. L.; RAIFFA, H. Decisions with Multiple Objectives: Preferences and Value Trade-Offs. Cambridge University Press, 1993.

KIM, H. S.; KIM, Y. G. A CRM performance measurement framework: its development process and application. Industrial Marketing Management, v. 38, n. 4, p. 477-489, 2009. http://dx.doi.org/10.1016/j. indmarman.2008.04.008

MILLET, I.; HARKER, P. T. Globally effective questioning in the Analytic Hierarchy Process. European Journal of Operational Research, v. 48, n. 1, p. 88-97, 1990. http://dx.doi.org/10.1016/0377-2217(90)90065-J

MORETTIN, P. A.; TOLOI, C. M. Análise de Séries Temporais. 2. ed. São Paulo: Editora Edgard Blücher, 2006.

RAFAELI, L. A análise envoltória de dados como ferramenta para avaliação do desempenho relativo. 2009. 166 f. Dissertação (Mestrado em Engenharia de Produção)-Universidade Federal do Rio Grande do Sul, Porto Alegre, 2009. Disponível em: <http://www.lume.ufrgs.br/bitstream/ handle/10183/16477/000701359.pdf?sequence $=1>$. Acesso em: 04 nov. 2010.

RAFAELI, L.; MÜLLER, C. J. Estruturação de um índice consolidado de desempenho utilizando o AHP. Gestão \& Produção, v. 14, n. 2, 2007. Disponível em: <http://www.scielo.br/scielo.php?pid=S0104530X2007000200013\&script=sci_abstract\&tlng=pt $>$. Acesso em: 04 nov. 2010.

RIBEIRO, L. S.; PASSOS, A. C.; TEIXEIRA, M. G. Seleção de tecnologias de comunicações no exército brasileiro utilizando os métodos multicritério de análise hierárquica, TODIM e software Sapiens. Produção, v. 22, p. 132-141, 2012. Disponível em: <http://www. scielo.br/pdf/prod/v22n1/aop_0006_0387.pdf > . Acesso em 15 nov. 2012.

SAATY, R. W. The analytic hierarchy process - what it is and how it is used. Mathematical Modelling, v. 9, n. 3-5, p. 161-176, 1987a. http://dx.doi. org/10.1016/0270-0255(87)90473-8

SAATY, T. L. A new macroeconomic forecasting and policy evaluation method using the analytic hierarchy process. Mathematical Modelling, v. 9, n. 3-5, p. 219-231, 1987 b. http://dx.doi.org/10.1016/0270-0255(87)90479-9
SAATY, T. L. How to make a decision: The analytic hierarchy process. European Journal of Operational Research, v. 48, n. 1, p. 9-26, 1990. http://dx.doi. org/10.1016/0377-2217(90)90057-I

SAATY, T. L. Fundamentals of Decision Making and Priority Theory with the Analytic Hierarchy Process. 2nd ed. RWS Publications, 2006.

SALA DE IMPRENSA. Prêmio IASC 2008 - Melhor Índice desde 2000. Portal DME Distribuição, 19 jan. 2009. Disponível em: <http://www.dme-pc.com. br/com_salaimprensa.php?Noticia $=48>$. Acesso em: 06 ago. 2010.

SANCHEZ-LOPEZ, R.; BANA E COSTA, C. A. The MACBETH approach for multicriteria evaluation of rural development projects in face of cross-cutting issues. Londres: London School of Economics and Political Science, 2009. 21 p. (Working Paper LSEOR 09.107). Disponível em: <http:// ww.lse.ac.uk/collections/operationalResearch/pdf/ LSEOR 09-107SanchezBanaeCostaCross-CuttingIssues. pdf $>$. Acesso em: 03 nov. 2010.

SARKIS, J. Quantitative models for performance measurement systems - alternate considerations. International Journal of Production Economics, v. 86, n. 1, p. 81-90, 2003. http://dx.doi.org/10.1016/ S0925-5273(03)00055-0

SELLITTO, M. A.; BORCHARDT, M.; PEREIRA, G. M. Avaliação multicriterial de desempenho: um estudo de caso na indústria de transporte coletivo de passageiros. Gestão \& Produção, v. 13, n. 2, 2006. Disponível em: <http://www.scielo.br/scielo.php?pid=S0104530X2006000200014\&script=sci_abstract\&tlng=pt>. Acesso em: 04 nov. 2010.

SOUSA, H. Publicação Eletrônica [mensagem pessoal]. Mensagem recebida por <adersoncp@gmail.com> em 14 abr. 2010.

SUWIGNJO, P.; BITITCI, U. S.; CARRIE, A. S. Quantitative models for performance measurement systems. International Journal of Production Economics, v. 64, n. 1-3, p. 231-241, 2000. http://dx.doi.org/10.1016/ S0925-5273(99)00061-4

VILLELA, F. R. Análise multicritério para a definição do índice de qualidade de fornecimento de energia elétrica por uma distribuidora. 2009. 157 f. Dissertação (Mestrado em Engenharia Elétrica)Pontifícia Universidade Católica do Rio de Janeiro, Rio de Janeiro, 2009.

ZAHEDI, F. The Analytic Hierarchy Process: A Survey of the Method and Its Applications. Interfaces, v. 16, n. 4, p. 96-108, 1986. http://dx.doi.org/10.1287/inte.16.4.96 ZOPOUNIDIS, C.; DOUMPOS, M. Multicriteria classification and sorting methods: a literature review. European Journal of Operational Research, v. 138, n. 2, p. 229-246, 2002. http://dx.doi.org/10.1016/ S0377-2217(01)00243-0 